\title{
Correction to: Alternative NADH dehydrogenase extends lifespan and increases resistance to xenobiotics in Drosophila
}

\author{
Dmytro V. Gospodaryov (1) Olha M. Strilbytska - Uliana V. Semaniuk • \\ Natalia V. Perkhulyn • Bohdana M. Rovenko - Ihor S. Yurkevych • \\ Ana G. Barata - Tobias P. Dick • Oleh V. Lushchak • Howard T. Jacobs
}

Published online: 27 January 2020

(C) The Author(s) 2020

\section{Correction to: Biogerontology \\ https://doi.org/10.1007/s10522-019-09849-8}

The article Alternative NADH dehydrogenase extends lifespan and increases resistance to xenobiotics in Drosophila, written by Dmytro V. Gospodaryov, Olha M. Strilbytska, Uliana V. Semaniuk, Natalia V. Perkhulyn, Bohdana M. Rovenko, Ihor S. Yurkevych, Ana G. Barata, Tobias P. Dick, Oleh V. Lushchak and Howard T. Jacobs, was originally published electronically on the publisher's internet portal on 20 November 2019 without open access. With the

The original article can be found online at https:// doi.org/10.1007/s10522-019-09849-8.

D. V. Gospodaryov · O. M. Strilbytska - U. V. Semaniuk · N. V. Perkhulyn · B. M. Rovenko - I. S. Yurkevych · O. V. Lushchak

Department of Biochemistry and Biotechnology, Vasyl Stefanyk Precarpathian National University,

Ivano-Frankivsk, Ukraine

D. V. Gospodaryov ( $\square)$

Department of Biochemistry and Biotechnology, Faculty of Natural Sciences, Vasyl Stefanyk Precarpathian National University, 57 Shevchenko Str.,

Ivano-Frankivsk 76018, Ukraine

e-mail: dmytro.hospodarov@pu.if.ua

Present Address:

B. M. Rovenko

Department of Biosciences, Institute of Biotechnology,

University of Helsinki, Helsinki, Finland author(s)' decision to opt for Open Choice the copyright of the article changed on 27 January 2020 to (C) The Author(s) 2020 and the article is forthwith distributed under a Creative Commons Attribution 4.0 International License (https://creativecommons.org/ licenses/by/4.0/), which permits use, sharing, adaptation, distribution and reproduction in any medium or format, as long as you give appropriate credit to the original author(s) and the source, provide a link to the Creative Commons licence, and indicate if changes were made. The original article has been corrected.
A. G. Barata · T. P. Dick

Division of Redox Regulation, DKFZ-ZMBH Alliance, German Cancer Research Center (DKFZ), Heidelberg, Germany

H. T. Jacobs

Faculty of Medicine and Health Technology, Tampere University, Tampere, Finland 
Open Access This article is licensed under a Creative Commons Attribution 4.0 International License, which permits use, sharing, adaptation, distribution and reproduction in any medium or format, as long as you give appropriate credit to the original author(s) and the source, provide a link to the Creative Commons licence, and indicate if changes were made. The images or other third party material in this article are included in the article's Creative Commons licence, unless indicated otherwise in a credit line to the material. If material is not included in the article's Creative Commons licence and your intended use is not permitted by statutory regulation or exceeds the permitted use, you will need to obtain permission directly from the copyright holder. To view a copy of this licence, visit http://creativecommons.org/licenses/by/4.0/.

Publisher's Note Springer Nature remains neutral with regard to jurisdictional claims in published maps and institutional affiliations. 